\title{
Character Association and Path Co-efficient Analysis Studies on Yield and Yield Attributing Characters in Chilli (Capsicum annuum L.) Germplasm
}

\author{
S. Chethan Kumar*, G.S. Sahu and Chandrakanth Kamble
}

Department of vegetable science, College of Agriculture, Bhubaneswar, OUAT, Odisha, India

*Corresponding author

\section{Keywords \\ Chilli, Phenotypic, \\ Genotypic, \\ Correlation \\ coefficient, Path \\ coefficient analysis \\ and yield}

Article Info

Accepted:

10 March 2019

Available Online:

10 April 2019

\section{A B S T R A C T}

The present study was conducted at AICRP on Vegetable Crops, Orissa University of Agriculture \& Technology, Bhubaneswar, and Odisha, India during rabi season of 2017-18 with an objective to study the correlation among the different traits in chilli genotypes for improvement in fruit yield and yield attributing traits. Thirty four genotypes were evaluated in a RBD with three replications. The genotypes were evaluated on the basis of 15 parameters that included growth and yield. Characters like average fresh fruit weight, number of fruits per plant, fruit girth, and average dry fruit weight were positively and significantly correlated to yield at genotypic and phenotypic level. However, significant negative correlations were found with days to initial flowering, days to $50 \%$ flowering and leaf area. Number of fruits per plant was found to exert maximum positive direct effect on yield followed by average fresh fruit weight, average dry fruit weight and fruit girth. Thus direct selection through the characters would be very effective in chilli improvement programme.

\section{Introduction}

Chilli or hot pepper (Capsicum annuum L.) native to new world tropics is one of the most important vegetable and spice crop in all over the world. In India, it is an indispensable spice cum vegetable in every household. Chilli belongs to family solanaceae of the genus capsicum with eleven species and the diploid chromosome number of this genus is $2 n=2 x=24$.

Correlation and path coefficient analysis provides information regarding the nature and magnitude of various characters associations and help in the measurement of direct influence of one variable on other.

The path analysis is a standardized partial regression coefficient, as it measures the direct effect of one variable upon other and permits the separation of correlation coefficient into components of direct and indirect effects of a set of independent variables on a dependent variable. Correlation coefficient analysis measures the mutual relationship between various plant characters and determines the component characters on which selection can be based for improvement in yield of chilli crop. 


\section{Materials and Methods}

Field experiments were conducted during Rabi season of 2017-18 at All India coordinated Vegetable Research project, OUAT, Bhubaneswar for evaluation, genotypes performance and genetic variability studies in chilli. The experiment was laid out in randomized complete block design (RCBD) with 34 genotypes collected from all over India namely, Utkal Rashmi, BC-7-2-2, BC-24-1, BC-7-2-1, BC-79-1, BC-27-2-2, BC-25, BC-28, BC-40-3-1-1, BC-40-2-1-1, BC-40-2, BC-21, BC-30, BC-7-1-1, BC-20, BC-70-2, BC-406, BC-5-1-7, BC-78-1, BC78-1-2, BC-43, Manipur local 1, Manipur local 2, Arka Abhir, Arka Lohit, Arka Suphul, Byadagi Kaddi, LAM-358, LAM-620, LAM625, Anugraha, Ujwala, Pusa sadabahar and Kunchinda local

\section{Results and Discussion}

In chilli, dry fruit yield is the economic character. The total fruit yield is the ultimate effect of interaction of several quantitative characters that are highly susceptible to changes in the environment. Hence, selection based on yield alone may not be a very sound proposition for effective selection. Various component characters which are directly and positively correlated with yield often act as useful indicators in the selection. Thus, sound knowledge of such associations among the various characters particularly in relation to total yield is of prime importance in planning successful and effective breeding programmes. According to Robinson (1966), correlation studies are helpful in choosing superior genotypes from the phenotypic expression.

The relationship of different characters with yield at genotypic and phenotypic level is presented in Table 1. The correlation estimates at phenotypic level $\left(r_{p}\right)$ and at genotypic level $\left(\mathrm{r}_{\mathrm{g}}\right)$ showed close correspondence for all character understudy.

The data presented in the Table 1 and Figure 1 revealed that phenotypic correlation $r_{p}$ ranged from 0.236 (between fruit length and plant height) to 0.913 (between average fresh fruit weight to average dry fruit weight). Out of 105 estimates of $r_{p}$ only 43 were found significant and among that 23 were positively significant, 20 were negatively significant and all other remaining $r_{p}$ were recorded as nonsignificant

The genotypic correlation coefficient presented in Table 1 and Figure 2 value ranged from 0.224 (between fruit length and plant spread NS $(\mathrm{cm})$ to 1.643 between plant spread EW to plants spread NS). Out of $105 \mathrm{r}_{\mathrm{g}}$ estimates of $r_{\mathrm{g}} 67$ were significant and among that 37 were positively significant, 30 were negatively significant and all the remaining $r_{g}$ were recorded as non-significant.

At phenotypic level dry fruit yield per plant was positively and significantly correlated with fruit length, fruit girth, average fresh fruit weight, average dry fruit weight, number of fruits for plant, plant height. However it had positive and non-significant correlation with other characters like number of primary branches, plant spread EW and plant spread NS.

At genotypic level dry fruit yield per plant was positive and significantly correlated with fruit length (0.507), fruit girth (0.646), average fresh fruit weight (0.726), average dry fruit weight $(0.659)$, number of fruits per plant (0.767), plant height (0.530) and plants spread NS (0.759).

However it had positive and non-significant correlation with other characters like number of fruits per plant and number of branches. Significantly negative correlation was 
observed with days to initial flowering, days to $50 \%$ flowering and leaf area with dry fruit yield per plant.

In the present study direct and indirect effect of different quantitative characters on dry fruit yield per plant were estimated through path analysis at phenotypic level presented in Table 2. Number of fruits per plant had the direct positive effect $(0.544)$ on dry fruit yield per plant. It exhibited high correlation with yield (0.605) via fruit girth (0.044) and leaf area (0.044).

The direct effect of average fresh fruit weight (0.302) was positive and it showed significant positive correlation with yield $(0.646)$ via average dry fruit weight $(0.201)$, fruit girth (0.075) and fruit length (0.026).

Average dry fruit weight showed positive direct effect (0.220) on fruit yield per plant and it exhibited high correlation with yield (0.580) viaaverage fresh fruit weight (0.276),fruit girth (0.065), and fruit length (0.028) andpedicel length (0.022).

Fruit length showed positive direct effect (0.044) on fruit yield per plant and it exhibited high positive correlation with yield (0.396) via average fresh fruit weight $(0.180)$ and average dry fruit weight $(0.139)$.

Fruit girth shows positive direct effect $(0.137)$ on fruit yield per plant and it exhibited positive correlation with yield (0.586) via average fresh fruit weight (0.165), average dry fruit weight (0.104) and number of seeds per fruit (0.174).

Pedicel length showed positive direct effect (0.086) on fruit yield per plant and it exhibited negative correlation with yield ($0.059)$ via number of seeds per fruit $(-0.173)$. Number of seeds per fruit recorded positive direct effect $(0.015)$ on fruit yield per plant and it exhibited negative correlation with yield (-0.158) via number of fruits per plant ($0.191)$, Leaf area showed the negative direct effect (-0.114) on yield per plant and it exhibited negative correlation with the yield $(-0.295)$.

Days to flower initiation showed negative direct effect on fruit yield per plant (-0.038) and it exhibited negative correlation with the $(-0.243)$. Days to $50 \%$ flowering showed positive direct effect (0.026) and negative correlation with the yield $(-0.175)$.

Plant height showed a positive direct effect (0.033) and positive correlation with yield (0.251). Number of branches showed positive direct effect on dry fruit per plant (0.039) and positive correlated with the yield (0.038) Plant spread EW showed negative direct effect (042) and exhibited positive correlation with yield (0.060) Plant spread NS showed negative direct effect $(-0.002)$ on dry fruit yield per plant and positive correlated with the yield (0.136).

The perusal of results of the present investigation exhibited that the genotypic correlation coefficients showed higher values for most of the variable pairs than the phenotypic correlation coefficients presented in Table 1, suggesting that there is a strong inherent association between the various characters studied.

Further, as the genotypic correlation coefficients showed a parallel value to the phenotypic correlation coefficients, it may be assumed that there is not much influence of environment in determining the association of these attributing characters with total yield and possibly due to a strong genitical makeup of the evaluated materials (genotypes). Wigan and Mather (1942) suggested that strong positive association of character with yield may be attributed to linkage and pleiotropy. 
Table.1 Phenotypic and Genotypic correlation coefficient between all pairs of quantitative characters studied in chilli

\begin{tabular}{|c|c|c|c|c|c|c|c|c|c|c|c|c|c|c|c|c|c|}
\hline No & Character & & $\begin{array}{c}\text { Fruit } \\
\text { Length } \\
\text { (cm) }\end{array}$ & $\begin{array}{l}\text { Fruit } \\
\text { Girth } \\
\text { (cm) }\end{array}$ & $\begin{array}{l}\text { Pedicel } \\
\text { Length } \\
\text { (cm) }\end{array}$ & $\begin{array}{l}\begin{array}{l}\text { Number } \\
\text { of }\end{array} \\
\text { Seeds/ } \\
\text { Fruit }\end{array}$ & $\begin{array}{c}\text { Avg. } \\
\text { Fresh } \\
\text { Fruit } \\
\text { Weight } \\
\text { (g) }\end{array}$ & $\begin{array}{l}\text { Avg. dry } \\
\text { Fruit } \\
\text { Weight } \\
\text { (g) }\end{array}$ & $\begin{array}{l}\text { Number } \\
\text { of Fruits } \\
\text { Per } \\
\text { Plant }\end{array}$ & $\begin{array}{c}\text { Days to } \\
\text { initial } \\
\text { flowering }\end{array}$ & $\begin{array}{c}\text { Days to } \\
50 \% \\
\text { Flowering }\end{array}$ & $\begin{array}{l}\text { Leaf } \\
\text { Area } \\
\left(\mathrm{cm}^{2}\right)\end{array}$ & $\begin{array}{c}\text { Plant } \\
\text { Height } \\
(\mathrm{cm})\end{array}$ & $\begin{array}{l}\text { Primary } \\
\text { Branches }\end{array}$ & $\begin{array}{c}\text { Plant } \\
\text { Spread } \\
\text { EW } \\
(\mathrm{cm})\end{array}$ & $\begin{array}{c}\text { Plant } \\
\text { Spread } \\
\text { NS }(\mathrm{cm})\end{array}$ & $\begin{array}{c}\text { Fruit } \\
\text { Yield Per } \\
\text { Plant (g) }\end{array}$ \\
\hline \multirow[t]{2}{*}{1} & \multirow[t]{2}{*}{ Fruit Length $(\mathrm{cm})$} & $\mathbf{p}$ & 1 & 0.033 & 0.112 & $0.338 * *$ & $0.597 * *$ & $0.633^{* *}$ & 0.036 & $-0.256 * *$ & $-0.223 *$ & 0.191 & $0.236^{*}$ & 0.044 & -0.045 & 0.088 & $0.396 * *$ \\
\hline & & g & 1 & 0.048 & 0.152 & $0.378^{* *}$ & $0.639 * *$ & $0.681^{* *}$ & 0.025 & $-0.318 * *$ & $-0.297 * *$ & 0.187 & $0.376^{* *}$ & 0.047 & 0.02 & $0.224 *$ & $0.507 * *$ \\
\hline \multirow[t]{2}{*}{2} & \multirow[t]{2}{*}{ Fruit Girth (cm) } & $\mathbf{p}$ & & 1 & -0.19 & -0.124 & $0.545^{* *}$ & $0.474 * *$ & $0.320^{* *}$ & $-0.269 * *$ & $-0.267 * *$ & $-0.282 * *$ & 0.002 & $-0.219 *$ & 0.077 & 0.178 & $0.586 * *$ \\
\hline & & g & & 1 & $-0.239^{*}$ & -0.142 & $0.599 * *$ & $0.510^{* *}$ & $0.380^{* *}$ & $-0.335 * *$ & $-0.334 * *$ & $-0.313 * *$ & 0.039 & $-0.238 *$ & 0.072 & $0.608^{* *}$ & $0.646^{* *}$ \\
\hline \multirow[t]{2}{*}{3} & \multirow[t]{2}{*}{ Pedicel Length (cm) } & $\mathbf{p}$ & & & 1 & -0.037 & 0.185 & $0.253^{*}$ & $-0.318^{* *}$ & $0.377 * *$ & $0.323^{* *}$ & $0.612 * *$ & 0.005 & 0.114 & -0.185 & $-0.232 *$ & -0.059 \\
\hline & & $\mathbf{g}$ & & & 1 & -0.035 & $0.200 *$ & $0.278^{* *}$ & $-0.385^{* *}$ & $0.441^{* * *}$ & $0.398 * *$ & $0.664 * *$ & -0.102 & 0.136 & $-0.642 * *$ & $-0.741 * *$ & -0.078 \\
\hline \multirow[t]{2}{*}{4} & \multirow{2}{*}{$\begin{array}{l}\text { Number of Seeds/ } \\
\text { Fruit }\end{array}$} & p & & & & 1 & 0.084 & 0.068 & $-0.351 * *$ & $-0.251^{*}$ & $-0.273^{* *}$ & 0.129 & 0.023 & -0.124 & 0.014 & 0.061 & -0.158 \\
\hline & & g & & & & 1 & 0.099 & 0.078 & $-0.412 * *$ & $-0.338 * *$ & $-0.390^{* *}$ & 0.154 & 0.135 & -0.147 & 0.094 & $0.266^{* * *}$ & -0.168 \\
\hline \multirow[t]{2}{*}{5} & \multirow{2}{*}{$\begin{array}{l}\text { Avg. Fresh Fruit } \\
\text { Weight (g) }\end{array}$} & $\mathbf{p}$ & & & & & 1 & $0.913^{* *}$ & $0.027 *$ & $-0.226^{*}$ & -0.188 & -0.036 & 0.159 & -0.076 & 0.009 & 0.085 & $0.646^{* *}$ \\
\hline & & g & & & & & 1 & $0.991 * *$ & 0.034 & $-0.302 * *$ & $-0.241^{*}$ & -0.051 & $0.300^{* * *}$ & -0.1 & -0.025 & $0.384^{* *}$ & 0.726 ** \\
\hline \multirow[t]{2}{*}{6} & \multirow{2}{*}{$\begin{array}{l}\text { Avg. dry Fruit } \\
\text { Weight (g) }\end{array}$} & p & & & & & & 1 & -0.056 & -0.19 & -0.162 & 0.041 & 0.181 & -0.066 & 0.051 & 0.091 & 0.580 ** \\
\hline & & g & & & & & & 1 & -0.065 & $-0.197 *$ & $-0.206 * *$ & 0.034 & $0.288^{* * *}$ & -0.072 & 0.068 & $0.402 * *$ & 0.659 ** \\
\hline \multirow[t]{2}{*}{7} & \multirow{2}{*}{$\begin{array}{l}\text { Number of Fruits Per } \\
\text { Plant }\end{array}$} & $\mathbf{p}$ & & & & & & & 1 & -0.121 & -0.05 & $-0.383^{* *}$ & 0.183 & 0.101 & 0.094 & 0.106 & $0.605^{* *}$ \\
\hline & & g & & & & & & & 1 & -0.147 & -0.128 & $-0.452 * *$ & $0.308^{* *}$ & 0.114 & $-0.217^{*}$ & $0.627 * *$ & 0.767 ** \\
\hline \multirow[t]{2}{*}{8} & \multirow{2}{*}{$\begin{array}{l}\text { Days to initial } \\
\text { flowering }\end{array}$} & p & & & & & & & & 1 & $0.779 * *$ & $0.323^{* *}$ & $-0.323 * *$ & $0.215^{*}$ & $-0.202^{*}$ & -0.02 & $-0.243 *$ \\
\hline & & g & & & & & & & & 1 & $0.986^{* *}$ & $0.349^{* *}$ & $-0.655 * *$ & $0.326^{* *}$ & $-0.604 * *$ & $-0.426 * *$ & $-0.282 * *$ \\
\hline \multirow[t]{2}{*}{9} & \multirow{2}{*}{$\begin{array}{l}\text { Days to } 50 \% \\
\text { Flowering }\end{array}$} & p & & & & & & & & & 1 & $0.335^{* *}$ & $-0.380 * *$ & $0.279^{* *}$ & $-0.239 *$ & $-0.263 * *$ & -0.175 \\
\hline & & g & & & & & & & & & 1 & $0.386^{* * *}$ & $-0.634 * *$ & $0.348^{* *}$ & $-0.911 * *$ & $-0.665^{* *}$ & $-0.257 * *$ \\
\hline \multirow[t]{2}{*}{10} & \multirow[t]{2}{*}{ Leaf Area $\left(\mathrm{cm}^{2}\right)$} & p & & & & & & & & & & 1 & -0.193 & -0.022 & $-0.354 * *$ & $-0.228^{*}$ & $-0.295 * *$ \\
\hline & & g & & & & & & & & & & 1 & $-0.266 * *$ & -0.010 & $-0.827 * *$ & $-0.652 * *$ & $-0.336 * *$ \\
\hline \multirow[t]{2}{*}{11} & \multirow[t]{2}{*}{ Plant Height (cm) } & $\mathbf{p}$ & & & & & & & & & & & 1 & -0.032 & 0.082 & 0.184 & 0.251 ** \\
\hline & & g & & & & & & & & & & & 1 & 0.019 & $0.210^{*}$ & $0.329 * *$ & 0.530 ** \\
\hline \multirow[t]{2}{*}{12} & \multirow[t]{2}{*}{ Primary Branches } & $\mathbf{p}$ & & & & & & & & & & & & 1 & -0.011 & -0.055 & 0.038 \\
\hline & & g & & & & & & & & & & & & 1 & 0.190 & -0.126 & 0.034 \\
\hline \multirow[t]{2}{*}{13} & \multirow{2}{*}{$\begin{array}{l}\text { Plant Spread EW } \\
(\mathrm{cm})\end{array}$} & $\mathbf{p}$ & & & & & & & & & & & & & 1 & -0.035 & 0.06 \\
\hline & & g & & & & & & & & & & & & & 1 & $0.991^{* *}$ & -0.091 \\
\hline 14 & Plant Spread NS & $\mathbf{p}$ & & & & & & & & & & & & & & 1 & 0.136 \\
\hline & $(\mathrm{cm})$ & g & & & & & & & & & & & & & & 1 & 0.759 ** \\
\hline
\end{tabular}


Table.2 Diagonal and indirect effect of component characters on yield in chilli genotypes

\begin{tabular}{|c|c|c|c|c|c|c|c|c|c|c|c|c|c|c|c|c|}
\hline No & Character & $\begin{array}{c}\text { Fruit } \\
\text { Length } \\
\text { (cm) }\end{array}$ & $\begin{array}{l}\text { Fruit } \\
\text { Girth } \\
(\mathrm{cm})\end{array}$ & $\begin{array}{l}\text { Pedicel } \\
\text { Length } \\
(\mathrm{cm})\end{array}$ & $\begin{array}{l}\text { Seeds/ } \\
\text { Fruit }\end{array}$ & $\begin{array}{c}\text { Avg } \\
\text { Fresh } \\
\text { Fruit } \\
\text { Weight } \\
\text { (g) }\end{array}$ & $\begin{array}{c}\text { Avg. } \\
\text { Dry } \\
\text { Fruit } \\
\text { Weight } \\
\text { (g) }\end{array}$ & $\begin{array}{c}\text { No. } \\
\text { Fruits } \\
\text { Per } \\
\text { Plant }\end{array}$ & $\begin{array}{c}\text { Days to } \\
\text { initial } \\
\text { Flowering }\end{array}$ & $\begin{array}{c}\text { Days to } \\
50 \% \\
\text { Flowering }\end{array}$ & $\begin{array}{l}\text { Leaf } \\
\text { Area } \\
\left(\mathrm{cm}^{2}\right)\end{array}$ & $\begin{array}{c}\text { Plant } \\
\text { Height } \\
\text { (cm) }\end{array}$ & $\begin{array}{l}\text { Primary } \\
\text { Branches }\end{array}$ & $\begin{array}{c}\text { Plant } \\
\text { Spread } \\
\text { EW } \\
\text { (cm) }\end{array}$ & $\begin{array}{c}\text { Plant } \\
\text { Spread } \\
\text { NS }(\mathbf{c m})\end{array}$ & $\begin{array}{c}\text { Fruit } \\
\text { Yield } \\
\text { Per } \\
\text { Plant } \\
\text { (g) }\end{array}$ \\
\hline 1. & Fruit Length $(\mathrm{cm})$ & 0.044 & 0.005 & 0.010 & 0.005 & 0.180 & 0.139 & 0.020 & 0.010 & -0.006 & -0.022 & 0.008 & 0.002 & 0.002 & 0.000 & 0.396 \\
\hline 2. & Fruit Girth $(\mathrm{cm})$ & 0.002 & $\mathbf{0 . 1 3 7}$ & -0.017 & -0.002 & 0.165 & 0.104 & 0.174 & 0.010 & -0.007 & 0.032 & 0.000 & -0.009 & -0.003 & 0.000 & 0.586 \\
\hline 3. & Pedicel Length $(\mathrm{cm})$ & 0.005 & -0.026 & 0.086 & -0.001 & 0.056 & 0.056 & -0.173 & -0.014 & 0.008 & -0.070 & 0.000 & 0.005 & 0.008 & 0.000 & -0.059 \\
\hline 4. & Seeds/ Fruit & 0.015 & -0.017 & -0.003 & 0.015 & 0.025 & 0.015 & -0.191 & 0.010 & -0.007 & -0.015 & 0.001 & -0.005 & -0.001 & 0.000 & -0.158 \\
\hline 5. & $\begin{array}{l}\text { Avg. Fresh Fruit } \\
\text { Wt. }(g)\end{array}$ & 0.026 & 0.075 & 0.016 & 0.001 & 0.302 & 0.201 & 0.015 & 0.009 & -0.005 & 0.004 & 0.005 & -0.003 & 0.000 & 0.000 & 0.646 \\
\hline 6. & $\begin{array}{l}\text { Avg.Dry Fruit } \\
\text { Weight }(g)\end{array}$ & 0.028 & 0.065 & 0.022 & 0.001 & 0.276 & 0.220 & -0.031 & 0.007 & -0.004 & -0.005 & 0.006 & -0.003 & -0.002 & 0.000 & 0.580 \\
\hline 7. & Fruits Per Plant & 0.002 & 0.044 & -0.028 & -0.005 & 0.008 & -0.012 & 0.544 & 0.005 & -0.001 & 0.044 & 0.006 & 0.004 & -0.004 & 0.000 & 0.605 \\
\hline 8. & $\begin{array}{l}\text { Days to initial } \\
\text { flowering }\end{array}$ & -0.011 & -0.037 & 0.033 & -0.004 & -0.068 & -0.042 & -0.066 & -0.038 & 0.020 & -0.037 & -0.011 & 0.008 & 0.009 & 0.000 & -0.243 \\
\hline 9. & $\begin{array}{l}\text { Days to } 50 \% \\
\text { Flowering }\end{array}$ & -0.010 & -0.037 & 0.028 & -0.004 & -0.057 & -0.036 & -0.027 & -0.030 & 0.026 & -0.038 & -0.012 & 0.011 & 0.010 & 0.001 & -0.175 \\
\hline 10. & Leaf Area $\left(\mathrm{cm}^{2}\right)$ & 0.008 & -0.039 & 0.053 & 0.002 & -0.011 & 0.009 & -0.208 & -0.012 & 0.009 & -0.114 & -0.006 & -0.001 & 0.015 & 0.000 & -0.295 \\
\hline 11. & Plant Height $(\mathrm{cm})$ & 0.010 & 0.000 & 0.000 & 0.000 & 0.048 & 0.040 & 0.100 & 0.012 & -0.010 & 0.022 & $\mathbf{0 . 0 3 3}$ & -0.001 & -0.004 & 0.000 & 0.251 \\
\hline 12. & Primary Branches & 0.002 & -0.030 & 0.010 & -0.002 & -0.023 & -0.015 & 0.055 & -0.008 & 0.007 & 0.003 & -0.001 & 0.039 & 0.000 & 0.000 & 0.038 \\
\hline 13. & $\begin{array}{l}\text { Plant Spread EW } \\
(\mathrm{cm})\end{array}$ & -0.002 & 0.011 & -0.016 & 0.000 & 0.003 & 0.011 & 0.051 & 0.008 & -0.006 & 0.040 & 0.003 & 0.000 & -0.043 & 0.000 & 0.060 \\
\hline 14. & $\begin{array}{l}\text { Plant Spread NS } \\
(\mathrm{cm})\end{array}$ & 0.004 & 0.024 & -0.020 & 0.001 & 0.026 & 0.020 & 0.058 & 0.001 & -0.007 & 0.026 & 0.006 & -0.002 & 0.002 & -0.002 & 0.136 \\
\hline
\end{tabular}


Fig.1 Phenotypic correlation coefficient between all pairs of characters studied in chili

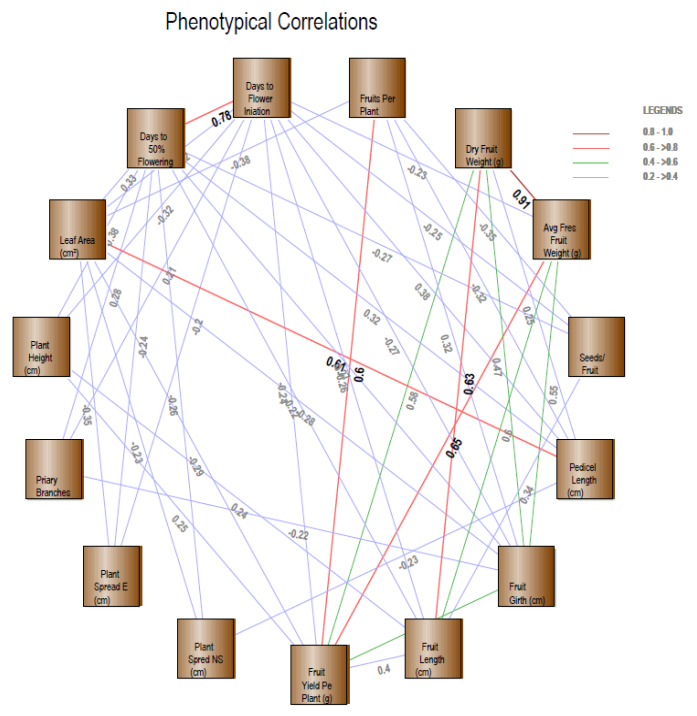

Fig.2 Genotypic correlation coefficient between all pairs of characters studied in chilli

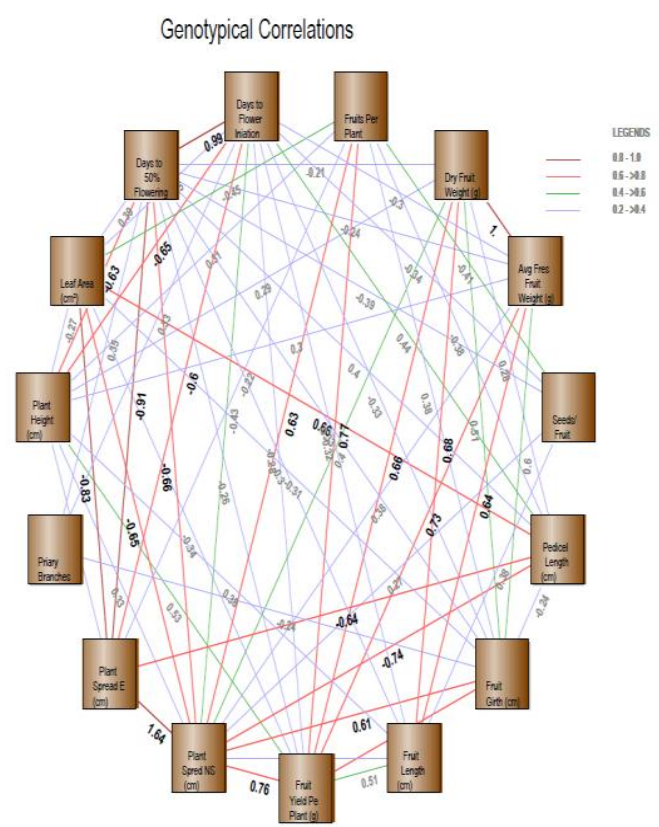

In the present finding significant and high positive correlation both at genotypic and phenotypic level for fruit dry yield per plant, fruit length, fruit girth, average fresh fruit weight, average dry fruit weight, number of fruits for plant, plant height. Low positive correlation was observed with the number of branches at both genotypic and phenotypic level and plant spread NS and EW at phenotypic level. However significant and 
negative correlation was observed with days to initial flowering days to $50 \%$ flowering and leaf area with both level. The present findings also corroborate the findings with Ajjappalavara et al., (2015), Smitha and Basavaraja (2006), Sharma et al., (2010) and Vikram et al., (2014)

Average fresh fruit weight it shows positive and significant correlation with fruit length, fruit girth and fruit yield per plant. However at both phenotypic and genotypic level it was negatively and significantly correlated with the days to initial flowering at both phenotypic and genotypic level. It is positively non-significantly correlated with pedicel length and plant height, plant spread.

The number of fruits for plants showed positive and significant correlation with fruit girth at both genotypic and phenotypic level. But it is negatively and significantly correlated with the traits like pedicel length, number of seeds per fruit, and leaf area genotypic, at level it is positively and nonsignificant correlate with character like fruit length, average fresh fruit weight, number of branches. it is evident from the observation that when number of fruits and average fresh fruit weight increases other component characters had also positive relation with them contributing to increase in yield. The present finding is in accordance with Smitha and Basavaraja (2016) and Sharma et al., (2010)

The correlations of above character suggest that selection for these component traits simultaneously will be effective in improving the yield in chilli. Other pairs of characters showing significant negative correlation value and insignificant value either positive or negative at phenotypic and genotypic levels, have least importance for effective selection based on these character.
Correlation coefficient which measures the association between any two characters may not give a true comprehensive picture in a complex situation. The associations between any two characters which are measured do not exist by themselves alone but are part of complicated pathway in which other traits are also interwoven. The indirect association becomes complex and important due to number of variables in correlation study. In addition to this, the mutual relationship among different characters which may be positive or negative make the situation complicated. In such situation, path coefficient analysis devised by Wright (1921) provides a better knowledge as it reveals direct and indirect causes of association and permits a critical examination of specific forces acting to produce a given correlation and measure the relative importance of each causal factor.

In the present study data presented in Table 2, number of fruits per plant was found to exert maximum positive direct effect on yield followed by average fresh fruit weight, average dry fruit weight and fruit girth. These findings are in agreement with the observations of Pujar et al., (2017), Shumbulo et al., (2017) and Shobha et al., (2017)

Fruit length, fruit girth and average dry fruit weight showed moderate positive indirect effect on dry fruit yield per plant. Thus direct selection through the characters like average fruit weight and number of fruits per plant would be very effective in chilli improvement programme.

\section{Acknowledgement}

I extend my deep sense of reverence and gratitude to AICRP on Vegetable crops, OUAT, Bhubaneswar, and Odisha for allowing me to take up my PG research work. I am highly thankful to ICAR for providing 
me financial assistance in the form of stipend to complete this endeavor.

\section{References}

Ajjapplavara, PS, Patil SS, Hosamani RM, Patil AA and Ganga Prasad S.2005. Correlation and path coefficient analysis in chilli, Karnataka Journal of Agricultural Sciences, 18 (3): 748751.

Pujar, UU, Tirakannanavar S., Jagadeesha RC, Gasti VD and Sandhyarani N. 2017. Genetic variability, heritability, correlation and path analysis in chilli (Capsicum annuum L.), International Journal of Pure Applied Bioscience, 5 (5): 579-586.

Smitha, RP and Basavaraja N., 2006. Variability and correlation studies in chilli (Capsicum annuum L.), Karnataka Journal of Agriculture Science, 19(4):888-891.

Sharma, VK, Semwal CS and Uniyal SP. 2010. Genetic variability and character association analysis in bell pepper
(Capsicum annuum L.), Journal of Horticulture and Forestry, 2(3):058065.

Shobha, BV, Tembhurne, Khan H, Naik MK and Patil BV. 2017. Genetic variability and association analysis for M 3 mutants in chilli (Capsicum annuum L.), Journal of Farm Sciences, 30(1): (16-19).

Shumbulo, A, Nigussie M and Alamerew S. 2017. Correlation and path coefficient analysis of hot pepper (Capsicum annuum L.) genotypes for yield and its components in Ethiopia, Advances in Crop Science and Technology,5(277): DOI: 10.4172/2329-8863.1000277.

Vikram, V, Warshamana IK and Gupta M. 2014. Genetic correlation and path coefficient studies on yield and biochemical traits in chilli (Capsicum annuum L.), International Journal of Farm Sciences 4(2): 70-75.

Wright, S. 1921. Corelation and causation. Journal of agricultural research, 20:557-585

\section{How to cite this article:}

Chethan Kumar, S., G.S. Sahu and Chandrakanth Kamble. 2019. Character Association and Path Co-efficient Analysis Studies on Yield and Yield Attributing Characters in Chilli (Capsicum annuum L.) Germplasm. Int.J.Curr.Microbiol.App.Sci. 8(04): 1051-1058. doi: https://doi.org/10.20546/ijcmas.2019.804.122 